\title{
Yenidoğanda Alkol İntoksikasyonu: Bir Olgu Sunumu
}

\author{
Alcohol Intoxication in Newborn: A Case Report
}

\begin{abstract}
Özmert M.A. Özdemir, Kazım Küçüktaşçı, Özlem Şahin, Alper Akpınar, Hacer Ergin

Pamukkale Üniversitesi Tıp Fakültesi Neonatoloji Bilim Dall, Denizli, Türkiye
\end{abstract}

Yazısma Adresi/Address for Correspondence Dr. Kazım Küçüktaş̧,, Pamukkale Üniversitesi Tip Fakültesi Neonatoloji Bilim Dall, Denizli, Türkiye Tel.: + 902584440728 E-posta:drkkucuktasci@gmail.com

Geliş Tarihi/Received: 28.08.2012 Kabul Tarihi/Accepted: 12.12.2012

20. Ulusal Neonatoloji Kongresi'nde poster olarak sunulmuştur.

(c) Güncel Pediatri Dergisi, Galenos Yayınevi tarafindan basilmıștir.

(c) The Journal of Current Pediatrics, published by Galenos Publishing.

\section{ÖZET}

Alkol intoksikasyonu yenidoğan döneminde oldukça nadirdir. Klinikte letarji, tremor, hafif ateş, hipoglisemi, hipotoni, solunum depresyonu ve koma bulguları görülmektedir. Intoksikasyon genellikle ailenin ihmali veya kazayla bebeğe alkol verilmesi șeklinde gelișmektedir. Tedavide temel prensip alkolün vücuttan eliminasyonu gerçekleşene kadar bebeğin klinik stabilizasyonunun sağlanması ve destek tedavisidir. Annesi tarafından yanlışl|kla \%70 etil alkol, gaz damlası sanılarak bebeğinin ağzına damlatılırken, açılan ilaç kapağından bolca alkol döküldükten sonra hastanemiz acil sevisine 25 günlük bir kız olgu getirildi. Fizik muayenesi normal, serum etil alkol düzeyi $12,3 \mathrm{mg} / \mathrm{dl}(0,12$ promil) saptandı. Klinik stabilizasyonu sağlanan ve sadece destek tedavisi uygulanan olgu dört gün sonra şifa ile taburcu edildi. Bu olgu sunumu ile yenidoğanlarda ilaç uygulaması konusunda ailelerin ve/veya bakıcıların iyi eğitilmesi gerektiği vurgulanmak istendi. (Güncel Pediatri 2013; 11: 39-41)

Anahtar kelimeler: Yenidoğan, alkol intoksikasyonu

\section{SUMMARY}

Alcohol intoxication is extremely rare in the neonatal period. Clinical presentation may be occurred by lethargy, tremor, mild fever, hypoglycemia, hypotonia, respiratory depression and coma. Intoxication usually appears as giving the baby alcohol with neglect of family or accident. The basic principle of therapy is support therapy and provision of clinical stabilization of the baby the elimination of alcohol from the body until it does. When the drops of $70 \%$ ethyl alcohol that her mother thought the gas drops unintentional was dripped to baby's mouth, lid of drug cover was opened and poured abundantly. Afterward, a 25 days old female case was presented to our hospital emergency service. Her physical examination was normal, serum ethyl alcohol level was $3.12 \mathrm{mg} / \mathrm{dl}$ (0.12 per mil). This case, that was provided clinical stabilization and applied only supportive therapy, was discharged four days later. In this report, we wanted to emphasize that family and/or caregivers should be well-trained drug administration in neonates. (Journal of Current Pediatrics 2013; 11: 39-41)

Key words: Neonate, alcohol intoxication

\section{Giriş}

Alkol intoksikasyonu genellikle kaza veya ailenin inmali sonucu gelişen ve hayatı tehdit edebilen ciddi bir durumdur (1). Yenidoğan döneminde oldukça nadir görülen alkol intoksikasyonu ile ilgili çok az sayıda olgu sunumu bulunmaktadır. Bu hastaların çoğu sadece destek tedavisiyle iyileşmektedir (2). Burada, yanlışlıkla gaz damlası sanılarak \%70'lik etil alkolün bebeğe damlatılması sırasında ilaç kapağının açılması ve bebeğin ağzına bolca dökülmesi sonucu hastanemiz acil sevisine getirilen bir yenidoğan olgusu sunuldu.

\section{Olgu Sunumu}

Miadında 3400 gr doğan kı bebek, 25 günlükken annesi tarafından gaz damlası sanılarak yanlışlıkla göbek bakımı için kullandığı \%70'lik etil alkolden yaklaşık 25 $\mathrm{ml}$ ağzına dökülmesinden 30 dakika sonra hastanemiz acil servisine getirildi. Genel durumu iyi, bilinci açık, vital bulguları stabil, fizik muayenesi normal ancak ajite olan olgunun tükürük sekresyonunda artış saptandı. Damar yolu açılarak rutin tetkikleri gönderilen olgu monitorize edildi, oral beslenmesi kesildi ve uygun sivi-elektrolit tedavisi başlandı. Alkol alımının birinci saati içinde mide lavajı uygulandı. Hemogram, periferik yayma, kan biyokimyası, tam idrar tetkiki, kan gazı, elektrokardiyografi (EKG) ve arka-ön akciğer grafisi normal olarak değerlendirilen olguda serum etil alkol düzeyi $12,3 \mathrm{mg} / \mathrm{dl}$ (0,12 promil) saptandı. Ağza dökülen alkolün göze temas etme riskinden dolayı yapılan göz muayenesi normaldi. Sadece destek tedavisi uygulanan olguda bir gün sonra serum etil alkol düzeyi $0,3 \mathrm{mg} / \mathrm{dl}$ 'ye düştü. Izlemde kliniği ve nörolojik muayenesi 
normal değerlendirilen olgu hastaneye kabulden 84 saat sonra şifa ile taburcu edildi ve poliklinik izlemine alındı.

\section{Tartıșma}

Etil alkol suda oldukça hızı çözünen, hücre içi ve hücre dışı ortamda kolayca dağılabilen, düşük molekül ağırlıklı hidrokarbon yapısına sahip bir moleküldür. Primer emilim ağız mukozasında bașlar, mide ve barsaklarda devam eder, ancak inhalasyon ve perkütan yolla da emilebilir. Emiliminde gastrik alkol dehidrojenaz enzimi önemli rol oynamaktadır. Etil alkolün \%90'ı karaciğerde, geri kalanı böbrek ve akciğerde metabolize edilmektedir. Karaciğerdeki enzim sistemleriyle asetaldehide, sonra asetaldehid dehidrojenaz enzimiyle asetik aside dönüșmektedir. Asetik asit krebs döngüsüne girip, karbondioksit ve su olarak ayrılmaktadır (2).

Hafif-orta alkol intoksikasyonunda hipotansiyon, ciltte kızarıklık, hipotermi, taşikardi, ürtiker, miyokard depresyonu, pupil cevabında değişkenlik, pulmoner sekresyonlarının temizlenmesinde azalma, diürez, ince motor kontrolde kayıp gibi klinik bulgular görülebilirken; ağır intoksikasyonda bradikardi, hipotansiyon, hipotermi, miyozis, kalp yetmezliği, akciğer ödemi, aritmi, solunum depresyonu, koma ve ani ölüm gelişebilmektedir (2). Yenidoğan döneminde ise letarji, tremor, hafif ateş, hipotoni ve koma bulgularıyla karşımıza çıkmaktadır (3-7). Etil alkolün glukoneogenezi inhibe etmesi, yenidoğanlarda göreceli olarak glikojen deposunun azlığı nedeniyle hipoglisemi daha sık gelişmektedir. Alkol santral sinir sistemi depresyonu, solunum depresyonu ve hipoksiye yol açabildiğinden hastalar mental durum ve nörolojik açıdan dikkatle değerlendirilmelidir (2). Bilinci açık, nörolojik muayenesi normal olan olgumuzda sadece ajitasyon ve tükürük sekresyonunda artış saptandı.

Yenidoğanlarda alkolün göbek bakımı sırasında alkollü petlerden cilt yoluyla emilmesi, süt veya mama dilüsyonu için su yerine yanlışılıla alkol kullanılması ve ateş düşürmek için alkol ile soğutma uygulanması alkol intoksikasyonuna neden olabilmektedir $(3,4,6,7)$. Bazı toplumlarda ailelerin infantil kolik tedavisi veya diş çıkarma esnasında huzursuzluk çeken bebekler için alkol içeren sıvılar kullanmalarına bağlı alkol intoksikasyonu olguları bildirilmiştir (2). Bizim hastamızda yanlıșlıkla gaz damlası sanılarak \%70'lik etil alkolün bebeğe damlatılması sırasında ilaç kapağının açılması ve bebeğin ağzına bolca dökülmesi sonucu intoksikasyon gelişmiştir.

Alkol intoksikasyonu düşünülen hastalarda serumda glikoz, elektrolit, üre, kreatinin, AST, ALT, Ca, Mg düzeyi, koagülasyon parametreleri, kan gazı bakılmalı, ozmolalite ve anyon gap hesaplanmalıdır. Aspirasyon şüphesinde akciğer grafisi, fokal nörolojik defisit veya kan alkol yüksekliğinin derecesiyle tutarsız mental durum değişikliği görüldüğünde beyin bilgisayarlı tomografisi (BT) çekilmelidir. Serum etil alkol düzeyi $200-300 \mathrm{mg} / \mathrm{dl}$ iken bilinç kaybı, 300$500 \mathrm{mg} / \mathrm{dl}$ civarında ise ölüm görülebilmektedir (2). Öyküde alkol alımının bilinmediği ve açıklanamayan letarji, koma durumlarında toksikolojik araştırmanın yapılması önerilmektedir $(3,4)$. Alkol alım öyküsü bilinen olgumuzda hemogram, tam kan biyokimyası, kan gazı, akciğer grafisi ve EKG normaldi. Serum etil alkol düzeyi $12,3 \mathrm{mg} / \mathrm{dl}$ saptandı. Bilinç düzeyi ve nörolojik açıdan normal değerlendirildiği için beyin BT çekilmedi.

Tedavide temel prensip, alkolün vücuttan eliminasyonu gerçekleşene kadar bebeğin klinik stabilizasyonunun sağlanması, bunun için destek tedavisi ve klinik bulguların yakın takibi önerilmektedir (1). Hastaların çoğu sadece destek tedavisiyle 4-6 saat içinde düzelmektedir. Hastalarda ilk olarak havayolu değerlendirilmeli, hasta iyi solumuyor veya aspirasyon riski varsa endotrakeal tüp ve "airway" takılmalıdır. Sıvı defisiti veya idame sıvı infüzyonu için damar yolu açılmalı, hipotansiyon durumunda volüm genişletici ve gerekirse vazopresörler verilmelidir. Hipoglisemi ve solunum depresyonu yaşamı tehdit eden en önemli iki komplikasyonudur. Hipoglisemi hızla düzeltilmelidir. Hipoglisemi tedavisinde glukagon etkili değildir. Hipotermik hastalarda vücut ısısı kademeli olarak arttırımalıdır. Hastalar kusturulmamalı, alkol alımından sonraki bir saat içinde getirildiyse oro/nazogastrik sonda ile mide içeriğinin boşaltılması ve mide lavajı yararlı olabilmektedir. Alkolü bağlayamadığı için aktif kömür verilmesi önerilmemektedir. Etil alkol metabolizmasının \%90'ı karaciğerde olduğu için zorlu diürez yararlı değildir. Etil alkole bağlı santral sinir sistemi veya solunum depresyonunda nalokson veya flumazenil gibi GABA reseptör antagonistlerinin etkinliği konusunda șüpheler bildirilmekte ve ilaç kullanımı önerilmemektedir. Invaziv bir işlem olması nedeniyle rutin uygulanması önerilmese de hemodiyaliz, kandan etil alkolün temizlenmesinde etkili olabilir. Klinik durumu bozulan, santral sinir sistemi veya solunum depresyonu görülen, standart tedaviye refrakter hipotansiyon ve karaciğer fonksiyon bozukluğu gelişen hastalarda diyaliz uygulanabilir $(1,2)$. Alkol alımından 30 dakika sonra hastanemize getirilen olguda nazogastrik sonda ile mide lavajı yapıldı, damar yolu açılarak tetkikleri istendi, iv uygun sıvı-elektrolit tedavisi başlandı ve monitorize edilerek yenidoğan ünitesinde izleme alındı. Izlem sırasında kliniği stabil seyreden ve nörolojik değerlendirmesi normal olan olguda 24 saat sonra serum 
etil alkol düzeyi $0,3 \mathrm{mg} / \mathrm{dl}$ saptandı. Olgu 84 saat sonra sağlıklı olarak taburcu edilip poliklinik takibine alındı.

Yenidoğan döneminde çok nadir olsa da kaza ve/veya inmal sonucu alkol intoksikasyonu görülebilmektedir. Bu olgu sunumu nedeniyle yenidoğan bebeklere verilen ilaç uygulamaları konusunda ailelerin ve/veya bakıcılarının özenle eğitilmeleri gerekmektedir.

\section{Kaynaklar}

1. Can $E$, Uslu $S$, Bülbül $A$, Cömert $S$, Bolat $F$, Nuhoğlu $A$. Yenidoğanda alkol intoksikasyonu: Olgu sunumu. Şişli Etfal Hastanesi Tıp Bülteni 2009;43:146-8.

2. Brothers $\mathrm{E}$, Doty $\mathrm{Cl}$. Ethanol toxicity. http://www.emedicine. medscape.com/article/1010220 01.04.2012.
3. Dalt LD, Dall'Amico R, Laverda AM, Chemollo C, Chiandetti L. Percutaneous ethyl alcohol intoxication in a one-month-old infant. Pediatr Emerg Care 1991;7:343-4.

4. Autret E, Sanyas P, Chantepie A, Gold F, Laugier J. Poisoning by externally administered ethanol in an infant. Arch Fr Pediatr 1982;39:823-4.

5. Mydler TT, Wasserman GS, Watson WA, Knapp JF. Two-weekold infant with isopropanol intoxication. Pediatr Emerg Care 1993 9:146-8.

6. Vivier PM, Lewander WJ, Martin HF, Kinakis JG. Isopropyl alcohol intoxication in a neonate through chronic dermal exposure: a complication of a culturally-based umbilical care practice. Pediatr Emerg Care 1994;10:91-3.

7. Palano GM, Praticò $A D$, Praticò $E R$, D’Agata $A$, Carpinato $C$, Sottile $\mathrm{F}$ et al. Accidental ethyl alcohol intoxication in a 30-dayold infant. Clinical findings and neurological follow-up. Minerva Pediatr 2007;59:275-9. 